\title{
Value Co-Creation Practices in Smart City Ecosystem
}

\author{
Marco Pellicano' $^{1}$, Mario Calabrese ${ }^{2}$, Francesca Loia ${ }^{3}$, Gennaro Maione ${ }^{1}$ \\ ${ }^{1}$ Department of Business Science-Management \& Innovation Systems (DISA-MIS), University of Salerno, Fisciano, Italy \\ ${ }^{2}$ Department of Business Studies, La Sapienza University of Rome, Rome, Italy \\ ${ }^{3}$ Departmentof Management, La Sapienza University of Rome, Rome, Italy \\ Email: pellicano@unisa.it, mario.calabrese@uniroma1.it, francesca.loia@uniromal.it, maione@unisa.it
}

How to cite this paper: Pellicano, M., Calabrese, M., Loia, F. and Maione, G. (2019) Value Co-Creation Practices in Smart City Ecosystem. Journal of Service Science and Management, 12, 34-57. https://doi.org/10.4236/jssm.2019.121003

Received: September 29, 2018

Accepted: January 8, 2019

Published: January 11, 2019

Copyright (c) 2019 by authors and Scientific Research Publishing Inc. This work is licensed under the Creative Commons Attribution International License (CC BY 4.0).

http://creativecommons.org/licenses/by/4.0/

(c) (i) Open Access

\begin{abstract}
Starting from the definition of smart cities, characterized by flexible information processes, innovation facilitation mechanisms, smart and sustainable solutions and platforms, the new urban scenario highlights the creation of value as the core purpose and the central process of exchange between actors. According to this consideration, the present work aims at re-reading smart cities in the light of value co-creation practices, trying to capture the factors that local administrators can leverage to pursue a more acute development of local communities. The work follows an exploratory approach by using, in particular, the single case model (holistic), with the purpose to analyse the value co-creation practices (Frow et al., 2014) in the context of smart city. Specifically, the city of Turin has been chosen, focusing on the initiative promoted along with the Torino smart city Foundation. Eight value co-creation practices are identified, in order to determine the set of attributes leading to the transformation process in smart cities. In addition, for each type of practice specific measures are identified. The work offers insights to improve the results pursued in different areas of administrative life. In fact, value co-creation practices highlight that an adequate combination of activities carried out by administrators, citizens-users, technology and other players in social life leads to improved performance in the urban sector. Furthermore, the work underlines the importance of value-added practices as tools to facilitate the involvement of several social actors, who are differently interested in contributing to the definition of processes of value generation. The innovative nature of the work arises from the authors' choice to analyse the theoretical background on practices in terms of co-created value and to connect these practices to smart cities, enabling arriving at a conceptual result steeped in value for scholars and practitioners interested in both business management and technology engineering.
\end{abstract}




\section{Keywords}

Value Co-Creation, Co-Creation Practices, Resource Integration, Value Co-Creation, Smart City, Service Management, Service Ecosystem

\section{Introduction}

The turbulence and complexity of the current environmental scenario make central the necessity of a new way to intend the urban context. In this regard, several scholars [1] [2] [3] highlight the importance of so-called smart cities, characterized by innovations concerning different fields, which have the potential to improve deeply human conditions. Flexible information processes, creativity and innovation facilitation mechanisms, smart and sustainable solutions and platforms are only few of the innovations present in these cities of future. These features suggest profound changes in the production and delivery of local public services, giving rise to an ever-growing involvement of all those who, in various respects, participate in value-generation processes.

Consequently, the participation and collaboration among the various social actors are made possible by new technological and social platforms that facilitate the sharing of resources between social actors [4] [5]. In fact, the changes that followed in the public administration contexts have also invested citizens' governments, increasingly called upon to offer a wide range of services that can increase the citizens' well-being.

This new urban scenario is in line with the innovative drive offered by the Service Dominant Logic, which emphasizes a different way of understanding the service and the relative delivery processes [6]. In particular, the creation of value can be considered as the core purpose and the central process of exchange between actors [7], also in the urban sector.

Starting from these considerations, the work aims at re-reading smart cities in the light of value co-creation practices [8], trying to capture the factors that local administrators can leverage to pursue a more acute development of local communities. To follow this goal, a case study was conducted on an example of intelligent city excellence in the Italian context.

Therefore, the work is structured in three sections. The former is focused on literature, highlighting how value co-creation practices can be identified within smart city ecosystems; in the second part, as anticipated, a case study is carried out about the city of Turin, and finally, the conclusions of the work are presented and discussed, highlighting also the relative theoretical and managerial implications of the work.

\section{Theoretical Background}

\subsection{Value Co-Creation Practices in the Service Ecosystem Perspective}

Starting from the definition in the field of science, the ecosystem can be consi- 
dered a community made up of different entities, which tend to adapt to changes in the environment [9] [10] [11]. In light of Service Dominant Logic, a service ecosystem perspective can be seen a model through which value creation can be better understood and, thus, businesses can be better informed [12]. In particular, sever scholars distinguish between three broad levels of an ecosystem: micro, meso and macro [13] [14]. In addition, other scholars [8] highlight the existence of a "mega" level, adopting an extended view of relationships.

Continuing, an ecosystem can be considered as a network of relationships linked together by interconnected practices [15]. In this regard, the interactions between the actors within an ecosystem can be constituted through practices based on shared understanding and are composed by tools, knowledge, images and physical space [16]. In particular value co-creation practices are interaction activities between more actors, which could be companies or any other subject of the considered ecosystem. The actors share their resources to make value proposals in the social context where they operate, maturing expectations toward the proposal that they receive [17]. The interactions between the actors facilitate co-creation experience whilst dialog, access, risk-benefits and transparency are the basis for this process [18].

The benefits associated to these practices can regard different aspects, as the customers' active involvement, which could bring to the innovative products development [18] [19] [20] [21] [22]. Furthermore, it is also possible that value co-creation practices are negative for the actors and bring to the co-destruction of value [23] [24].

There are many categorizations about practices. Kjellberg and Helgesson [25] give a first categorization about market practices, subdividing them in: "exchange practices" (activities that stabilize market practices); "representational practices" (activities that represent the market through symbols, figures and statistics); and "normalizing practices" (activities that set the legal laws). Therefore, the conceptual model presents markets as the result of three interlaced types of practices and explains the differences about how markets are constantly realized. Another categorization of practices is proposed by Skålén et al. [26] who find ten common practices, ordered in three main groups that constitute and realize value propositions. The groups are composed by "provision practices" (operative activities that support the value creation processes); "representational practices" (activities that communicate the meaning of the value proposition); and "management and organizational practices" (activities that support in achieving of the value proposition). Other scholars contribute developing typologies of co-creation practices in health care service ecosystem, identifying some practices with positive effects and/or other ones with negative effects, providing indicative measures of co-creation [8]. In particular the co-creation practices are eight: practices that endow actors with social capital; practices that provide an ecosystem with a shared language, symbols, signs and stories; practices that shape an actor's mental model; practices that impact the ecosystem, created or constrained by the physical structures and institutions that form their contexts; practices that shape 
existing value propositions and inspire new ones; practices that impact access to resources within an ecosystem; practices that forge new relationships, generating interactive and/or experiential opportunities; and practices that are intentionally co-destructive creating imbalance within the ecosystem.

In addition, other authors used the concept of "practice". DeVries et al. [27] wrote about educational practices, reporting the results of a four-year research project where a method of collaboration is developed by experienced teachers and students in accordance with the principles of educational action research. This approach is based on teaching and learning issues selected by the experienced teachers. Furthermore, Golooba and Ahlan [28] investigate the concept of practices related to the service value co-creation in research and innovation in higher education institutions in Malaysia. The goal of them work was to increase the volume and value of research through a platform that integrated and shared resources for each benefit. Lastly, Langley [29] discussed about creative practices as a way to co-create knowledge. In his work, the design is considered not like a science or an art but like a practice, that can take advantage of science and technology. In this sense, participatory design has the potential to connect people and communities and the relating different ideas could create co-creation. Therefore, the co-creation practices are activities, where actors collaboratively engage in activities through interactions within a specific social context [8].

\subsection{Analyzing Smart City Ecosystem in Terms of Co-Created Value}

Nowadays, in several Countries, the concept of smart city influences the vision of the future urban development [3]. Often, different cities have defined themselves as smart but the meaning attributed to this word is different each time [30]: smart city can be considered as the city of knowledge, pervasive city, sustainable city or also digital city, depending on the different connotation of the term "smart" [31]. Dameriqualifies the smart city as "a well defined geographical area, in which high technologies such as ICT, logistic, energy production, and so on, cooperate to create benefits for citizens in terms of well being, inclusion and participation, environmental quality, intelligent development; it is governed by a well defined pool of subjects, able to state the rules and policy for the city government and development", highlighting the strong relation between land, citizens, technology and governance [31]. This concept can integrate the ICT tools with the various physical devices using enabling technologies (Internet of things or IoT) to optimize the efficiency of operations and services and connect the citizens [32]. In this direction, from the studies carried out, it is evident that the key factors of success for a smart city concern three main dimensions, strongly connected: technology, people and institutions [33]. Indeed, the goal is to integrate different infrastructures and services through the central role of the technology and learn social aspects to strengthen human infrastructures and governance for the institutional improvement and citizen's engagement. The value of smart cities reflects not only as a model of government geared to addressing 
pollution issues, congestion and scarcity of resources, but also as a tool to reach a greater social and territorial aggregation. In fact, an intelligent government approach aims, above all, to exploit and coordinate citizens' enthusiasm and skills so to represent their interests more effectively and effectively. The awareness of the potential of adopting a smart city lead to the emergence of socially creative innovations, which in turn can ensure an increase in citizen confidence and the development of collaboration agreements between the various social actors involved. On this wake, other scholars [34] [35] have highlighted how smart cities, understood as true learning organizations, are able not only to create, develop and acquire knowledge but especially to influence the behavior of people and organizations through the exploitation of new knowledge and skills.

In this regard, collaborative relationships within a smart city allow overtaking traditional partnerships between public sector organizations, leaving space for the spread of government models that can generate greater value than the sum of the individual parties involved in development processes. The creation of this greater value is generated by the creative and profitable interaction between suppliers and users of services [36]. Similar considerations show how the use of the ICT is not sufficient for the birth and dissemination of smart cities, but it is also necessary to activate as profitable as creative networks of stakeholder relations, in various ways, concerned with value-generation processes. In other words, technological platforms designed to ensure high-tech performance must be properly integrated into social platforms, thus enabling all concerned to become an active part of value creation mechanisms [37]. This shift of perspective tends to give a different role to the technological and social platforms, increasingly called as facilitators for the activation of collaborative networks among social stakeholders [38]. Indeed, the participation of the various social actors is a necessary and sufficient condition to encourage the citizen-users commitment to value-creation processes, so to change their individual and collective behaviour by directly acting on the social norms that they recapture.

These arguments are consistent with those proposed by the Service-Dominant Logic, which promotes a real change of perspective that can reverse the comparison in terms of the prevalence of tangible and intangible assets in favor of the latter [7]. In fact, the smart cities model, predominantly based on the collaboration between actors involved in public service delivery processes, seems to be re-readable in light of S-D Logic propositions. S-D Logic propositions push for greater involvement of all social actors, not only as recipients of such services, but as protagonists able to play an active role in value creation processes, in terms of feedback and collaboration, their profitable contribution to the generation of a value greater than the sum of the individual parts.

The various social actors are encouraged to co-create value, together and without prevalence of functions and roles, if they are guided by a common purpose. Such collaboration, then, becomes effective with the support of advanced technological instruments [39], like in smart cities. The latter, as already men- 
tioned above, represent a model of government comparable to a service eco-system in which people, technology and institutions, as represented in Figure 1, are appropriately combined to generate a value that is then redistributed to all those who, in different measure and way, participate in its determination [40].

\section{Research Methodology}

With the purpose to re-read smart cities in the light of value co-creation practices, a case study was carried out to highlight practices used in the urban sector. In fact, considering a context where it is trying to investigate the reasons that led to the birth and dissemination of a contemporary set of events, because the researcher has no control or, in any case, manages to exercise a very contained control, the methodology of a case study seems to be more appropriated.

Case studies present numerous strengths represented by the depth of analysis, high conceptual validity, understanding of context and process, and finally the possibility of promoting new hypotheses and new research questions [41].

Indeed, it is possible to describe this research technique as "an empirical research where data is not produced in the form of numbers" [42]. In fact, according to scholars oriented towards a qualitative approach [43] [44] [45], a case study is able to "describe moments, meanings of routines and problems relating to the lives of individuals. It uses a wide range of interconnected methods, always hoping to get a better solution on the topic of interest" [44]. Continuing, other scholars [43] highlight how the case study is able to highlight the meanings that individuals attribute to a subject within a natural environment. In fact, this methodology can provide a detailed analysis aimed at gathering information about an object, event, or specific activity.

Therefore, in this work, in order to re-read smart cities in the light of value co-creation practices, the example of Turin was considered, an Italian city highly focused on the smart cities model [45] [46]. In this regard, the work deals with

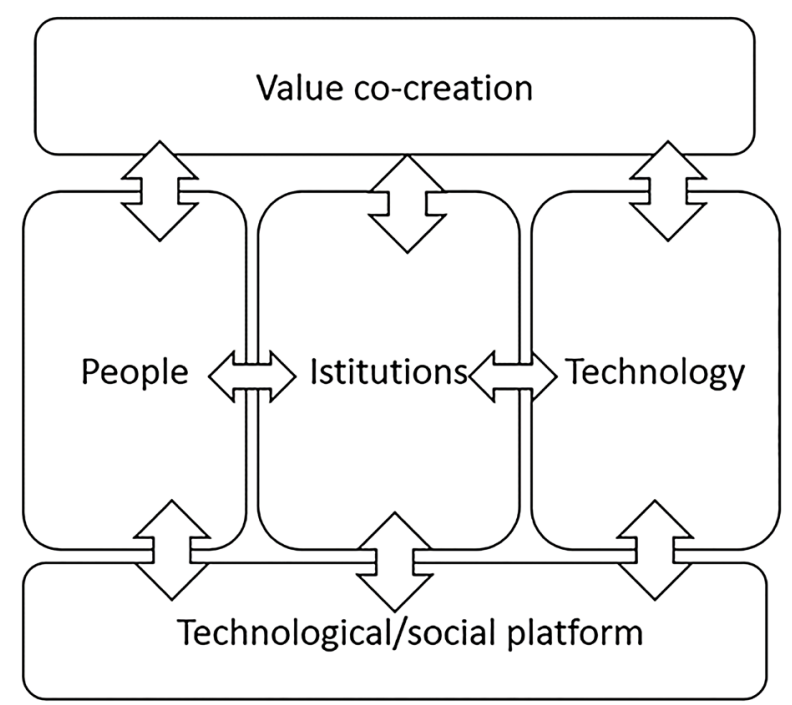

Figure 1. Dimensions of smart city ecosystem in terms of co-created value. 
the initiative promoted by the City of Turin together with the Torino smart city Foundation, with which in February 2013 a strategic planning process lasting more than six months led to the elaboration of the Master Plan SMILE (Acronym of Smart Mobility, Inclusion, Life and Energy).

In particular, the case study was conducted through the implementation of seven semi-structured interviews, submitted to local administrators and managers involved as decision makers in the SMILE Master Plan. Interviews were conducted over a period of five months and lasted about two hours. The interviews were all composed of the same questions, in order to avoid conditioning the results. Furthermore, all the interviews were audio-recorded and subsequently slavishly transcribed. More in detail, each interview was composed of the following questions: 1) What is for you a smart city? 2) What are the smart city actors? 3) What kind of relationship is there between the various smart city actors? 4) What benefits does the interaction between the smart cities' actors produce in terms of value co-creation? 5) What actions (practices) do local administrators undertake or should they undertake to encourage the development of local communities?

In addition to a primary research, a secondary research was conducted with regard to the relevant documents represented by the reports correlated to the SMILE Master Plan. The comparisons with the local administrators in Turin and the managers involved in the initiative was useful in collecting information and elements capable of highlighting the dynamism, effectiveness and potential of value-added practices.

\section{The Case of Torino SMILE Project}

Starting from deep and unresolved urban problems (high degree of bureaucracy, complexity of processes, excessive urban traffic, etc.), several scholars [1] [2] [3] have been focused on smart cities, in order to find a possible solution to manage urban difficulties which, for too long, have afflicted both large and small cities. The constant technological revolution can be considered as an important means to reach this goal, and, in this regard, a suitable combination of new ICTs (Information and Communication Technologies) and organizational planning could allow the dematerialization of economic processes, simplification of service delivery processes and reduction of the degree of bureaucracy existing in administrative proceedings [46].

Therefore, considered the complexity of the current scenario and the emergence of the ICT development [47], several cities have begun the race to become a smart city. In this direction, the Italian city Turin, gathering the challenge launched in 2011 by the European Committee with the initiative "smart cities \& Communities", is trying to become the protagonist of a technological revolution. In particular, the local government has developed several processes aimed at responding to the main territorial problems in the following fields: energy, environment, mobility, accessibility, inclusion and integration, life and health. 
Therefore, the city has participated to European and Italian calls, launching and developing research projects, regarding technological innovation aspect.

Seeing the urban context as an evolving ecosystem, the proposed value offerings, available resources and co-creation practices manifested play a central role [8]. Consequently, in this work, the value co-creation practices are identified in order to determine the set of attributes that lead as a result to the transformation process in smart cities. In addition, for each type of practice specific measures are identified. In particular, each type of practice identified is based on the relevant literature and reflects co-creation practices that are particularly evident in the context of smart city. Specifically, the work highlights eight value co-creation practices, as depicted in Figure 2, that represent a new approach for considering the process to become a smart city. In the discussion that follows, each practice is described.

\subsection{Social Capital Practices}

During the 1990s, social capital has been defined as the set of rules and networks that allow people to act collectively. In particular, through the growth and evolution of social capital, also the economic aspect can be developed reaching a strategic advantage [48]. This is possible through four different approaches: community, networks, institution and synergy.

In particular, an opportune management of social capital can create value and lead to success pointing on the collective action [49]. In this regard, co-creation

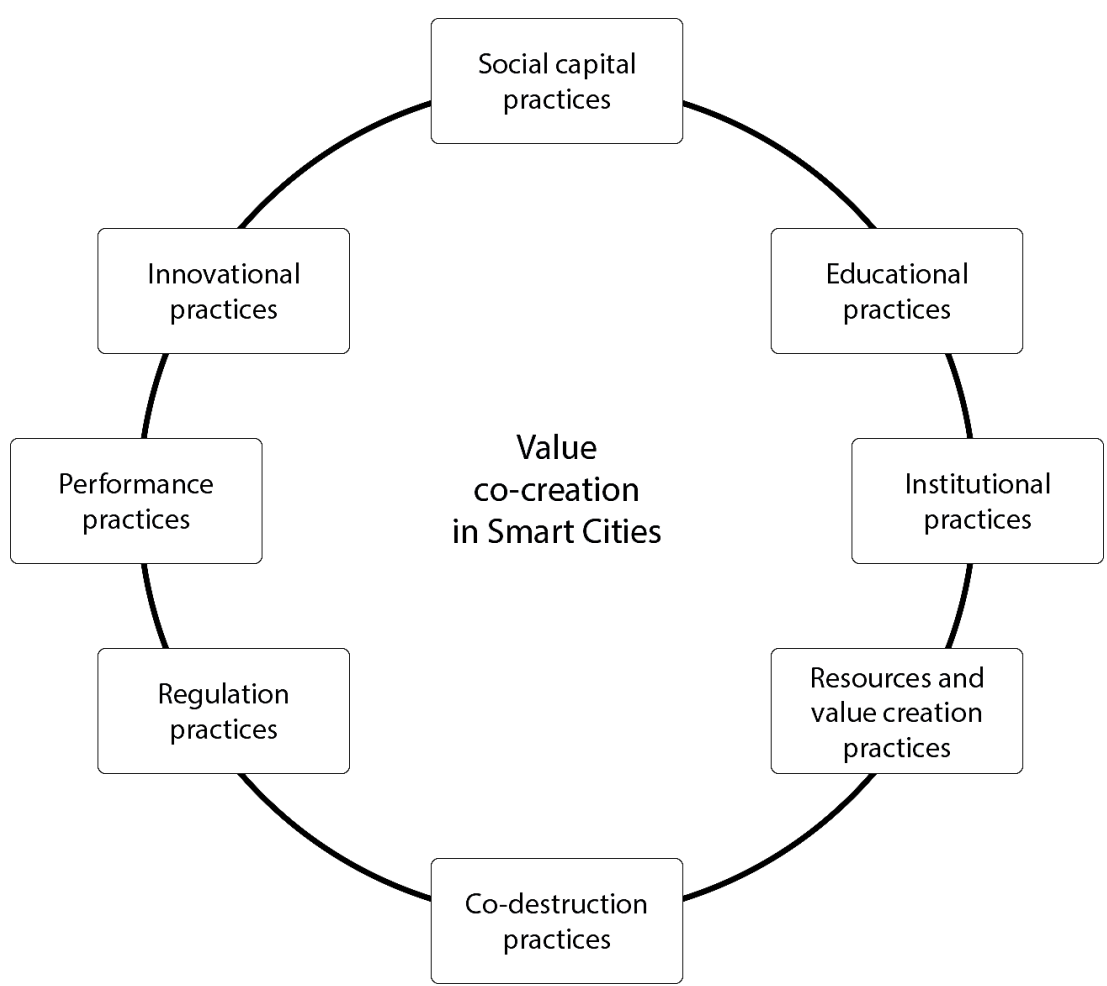

Figure 2. Value co-creation practices that impact the well-being of the smart city ecosystem. 
practices can strengthen social capital through an intensification of actors' interactions, influencing their social situation and their degree of influence within the considered ecosystem [50].

Therefore, even considering the urban context, the performance of the city ecosystem does not depend only on physical capital, such as physical infrastructures, but also on human and social capital represented by the availability and quality of the knowledge communication and social infrastructure. Therefore, to make a city increasingly competitive it is necessary to improve communication and social infrastructures [51].

Through the analysis of the Torino SMILE project, a planning process has been developed including 55 people, 5 research centers, 23 institutions, 10 associations and many people, organized on work tables, coordinated by Torino Wireless in a cycle of 5 meetings and over a period of 150 days. The aim of these meetings was to share ideas and visions from different roles to achieve benefits through these dynamic interactions [52]. The outcome is the first Master plan of Turin called "SMILE", able to pointing up the City's assets, national and international best practices, the project ideas on vertical themes, governance and sustainability models. As a result, this tool, setting the model of intelligent city, can guide in the identification of development trajectories, objectives and priorities, through strategic actions and key projects, promoting sustainable and replicable models and solutions to enhance local specificities [52].

First, it emerged that the parties have a different background and for this reason it is possible to analyze dissimilar points of view on the questions. Secondly, cooperation and collaboration between the various stakeholders helps to increase trust between the parties. Finally, the influences of different ecosystems can lead to the development of new projects and the creation of innovative ideas [53] [54].

An important aspect was the sharing of the final objective and the explanation of the values and principles to all the participants from the training in the management of the smart city [55].

A possible indicative measure of the co-creation practices of this type concerns the density and the volume of interaction that are developed in a particular ecosystem [56], considering the participation of citizens in the governance of cities as a factor that can influence urban performance [57]. In particular, it can be concretized by developing social infrastructures (intellectual capital and social capital), indispensable endowment to smart cities [33] [51].

\subsection{Educational Practices}

Educational practices recover another important role in the value co-creation process. [58] define education as "the most important predictor of political and social commitment". Thus, education, understood as the process by which communities learn and share knowledge, can influence, at different levels, the success of a country, a region or a nation [59]. Furthermore, educational expres- 
sions are also social benefits deriving from the education of every individual that can benefit others in today's society and in future generations [60].

In particular, educational practices require a shared language, symbols, signs and stories [8]. First, the shared language allows the strengthening of social capital, which, in turn, influences the sharing of individual knowledge in the communities [61]. Continuing, signs are part of everyday life and well designed and planned signs can make communication simpler and more direct. Instead, a symbol is the basis of a sign and has the purpose of conveying an idea that cannot be fully expressed by words [62]. Furthermore, stories are fundamental for both professional development and personal understanding [63].

Thus, practices that have common language, symbols, signs and stories can influence the actors' mental model, reinforcing their interactions with others and their activity performances. For instance, the influence of shared mental models was tested on teams and the results demonstrated the efficiency increase in team by performing interventions designed to achieve convergence of mental models [64].

As regards the territory, education regarding the urban environment is positively correlated with urban wealth. Therefore, it is important to formulate a strategic program for cities that allows achieving sustainable urban development and a better urban scenario [51].

Considering the SMILE project, educational practices play a particularly important role in the success of the project. Indeed, to achieve this goal the General Plan was written to define the actions of each individual, from citizens to experts, and establish the methodology, best practices and main actions that users have to perform to align them with the general objective of the smart city.

In particular, the 750-page document collects and presents city assets, national and international best practices, 45 project ideas on vertical themes (mobility, social inclusion, lifestyles and prevention, energy and integration), governance models and sustainability models of the smart city [65]. This document has become the operative reference point for the organization of the activities in the urban sector and can be a drive to reach a higher competitiveness in this context. The main role of this strategic planning is to improve the overall urban infrastructures and services in the view to achieve better environmental conditions, to maximize connectivity and to enhance opportunities for all, putting the user at the center of development policies.

Therefore, in that document, language, symbols and shared signs are used to guarantee a shared mental model for the actors of the ecosystem in order to ensure the dissemination and understanding of the project aims. In fact, with this document, Turin is one of the first Italian cities to propose strategic development lines that are at the base of the definition of a large number of project ideas, timely and shared with a wide range of stakeholders interested in planning and implementing the future of the city. Each project idea is accompanied by a description that identifies the places concerning the initiative, all the actors in- 
volved, the expected benefits and links with existing initiatives. Regarding a possible way to measure educational practices, it is evaluated the extent of the dissemination and use of symbols, signs and stories among the relational ecosystem actors [8] [66]. In addition, the change in co-creation practices and in actors' worldview can be relevant as a way to measure educational practices [67] [68]. In this regard, it can facilitate the process of adoption of a community agenda with programs aimed at social learning, education and social capital and focus on social and environmental sustainability from the communities [33] [69].

\subsection{Institutional Practices}

Snyder [70] defines institutional practices as practices arising from empirically founded forces and influencing different social aspects. In the context of smart city, an important dimension concerns the institutions, in particular the governance policies put in place for institutional improvement and to encourage the commitment of citizens [33].

In 2009, a cohesion policy was set up to foster the vision of the territorial dimension as a fundamental completion for achieving economic goals and social cohesion. In particular, the European Commission has focused on cities and urban areas that fall within the competence of the European Union, thanks both to the Treaty on the functioning of the EU (2008) and the Treaty of Lisbon (2009). The proposals attached to the 2014-2020 cohesion policy regulations package, with regard to urban development, are mostly geared towards supporting integrated policies for sustainable development. In this direction, the main proposals mainly concern the adoption of integrated investment strategies oriented towards a more global approach [71] [72]. In particular, the city of Turin accepted the challenge launched by the European Commission in 2011 with the smart cities \& Communities initiative to become a "smart city". In addition to defining appropriate stimulus and support measures under the Europe 2020 strategy and the next 2014-2020 financial period, the city intends to develop processes and paths to address key territorial problems in the following areas: energy, environment, mobility, accessibility, lifestyles, inclusion and social cohesion. Therefore, the European Commission establishes projects and provides shared rules for the actors who have to carry out certain activities in order to achieve the agreed common goals.

Regarding a possible measure of institutional practices, an evaluation can be considered the extent to which rules, norms and procedures change over time together with their impact [73]. In this measure, all the interventions, implemented by not only European and international institutions but also by regional institutions and local stakeholders [40]-[51] are considered.

\subsection{Resources Management and Value Creation Practices}

An appropriate resources management is essential to ensure the survival of any 
system. In particular, when service systems interact through relationships that allow the exchange of reciprocal services, it is also possible to integrate resources achieving a mutual advantage for all the actors that interact in the system considered [7]. Thus, during this integration phase, the actors involved produce a dialogue and transfer resources for the creation and renewal of resources for the purpose of co-creating value [74].

Therefore, the resources management practices define the necessary resources and operational methods to manage resources in order to co-create value. These practices aim to organize integrated resources through the alignment of practices [75]. In particular, actors share their own resources also to obtain new resources from other actors. Consequently, resource management practices are also co-creation practices [8].

In the smart city context, actors and entities must be involved in initiatives and share resources to define the market and customer needs [75].

In the activities launched by the Masterplan project of SMILE, there are nine activities under the name of "integration", which aim to integrate resources through better communication, adequate infrastructures and suitable data management. These activities concern digitization projects and social participation. Through a greater sharing of resources, new and existing value propositions are proposed with greater intensity.

Therefore, a possible measurement of such practices consists in the extent to which resources are shared by all actors within an ecosystem [76]. Also, the evaluation of the extension of the actor's perception regarding the value proposition [74] and the articulation new propositions [67] contribute to this measurement. In this regard, the sharing resources in a smart city recover a central role in order to create establishing urban and regional innovation ecosystems reaching a sustainable partnerships and cooperation strategies among the main stakeholders [41].

\subsection{Co-Destruction Practices}

Previous studies show that interactions do not always create value, but sometimes the formation of interactive value is associated with the co-destruction of value [23]. In particular, the process of value co-destruction derives from the improper use of the resources by the actors. To avoid potentially destructive collaborations, it is necessary to identify the interactive process associated with these negative results of co-creation practices [77] or to choose collaborations and interactions which are less risky [78].

Therefore, value bids are determined individually, which implies that the same offer can entail different levels of value for different actors [6], so a value bid can be relevant to an actor, but, at the same time, detrimental to another actor who participates in the exchange. The co-destruction of value consists precisely in this effect. In particular, this refers not only to the decline in value, but also to the negative change compared to high expectations on some delivery services. 
Considering the context of smart cities, there are some interactions that can lead to a co-destruction of value. In the SMILE project there has been an investment of resources in project proposals that have not received approval. Indeed, the city of Turin has given its support to 18 research projects submitted to the MIUR 2012 smart cities and social innovation announcement but only 6 have received funding. Even when there are collaborations with negative results of co-creation practices, in any case new collaborations occur that in the future can lead to positive and beneficial results in the co-creation of value.

Regarding a possible measure of these practices, it is possible to consider the extension of the number of actors who renounce to interact in the ecosystem [79] and the number of actors with a conflicting role belonging to several ecosystems can be considered [13]. Focusing on the smart city context, several complications and value co-destruction practices regard the difficulty to attract investments, especially, regarding to the lack of a clear and widely accepted business model, for instance regarding the IoT paradigm [80].

\subsection{Regulation Practices}

In order to co-create value, another important role is played by regulation practices. In fact, starting from the limits of the institutional theory, it is possible to incorporate an approach based on practice in the markets. In particular, empirical studies were carried out by Kjellberg and Helgesson [81] who defined the normalization, representational and exchange practices. These practices are part of a model used to illustrate the differences in the way markets are continually implemented. First of all, the normalization practices are aimed at establishing guidelines, rules and procedures concerning the markets. Therefore, the purpose of these practices is to establish regulatory goals. Continuing, the representative practices aim to represent markets and its mechanisms through statistics, figures and indices. In particular, the representation of market makes possible to arrive at a more manageable and understandable form of the latter. Finally, exchange practices cover activities such as individual economic exchanges, the presentation of a product, the setting of a price and the terms of payment and delivery. These activities establish the conditions necessary for economic exchange.

Also with regard to the smart cities and the interactions created in this ecosystem [82], market practices recover a fundamental role.

Concerning normalization practices, in the urban context it is necessary to regularize the exchange between the actors through guidelines and rules defined appropriately. For this reason, European and national calls are defined to normalize the relationship between the European Commission and the city, the exchanges and the respective responsibilities between the different actors.

These calls are particularly useful in launch research projects, technological development and innovation connected to the themes of the "smart city". At the European level, the city of Turin, on its journey to become a smart city, has participated to several regulated candidate projects such as the CIP (Competitive- 
ness and Innovation Program), VII Framework Program, Interreg and Urbact II CIP. The launch of these projects has allowed improving the strategic aspect concerning topics such as mobility, energy, environment, innovation provision and so on.

Continuing the discussion, the representative practices allow providing information about the results achieved by the cities. The "smart city index" has been defined to summarize the results and achievements of cities in the urban transformation process. In particular, in 2014, it highlighted the progress achieved by the city of Turin, which has moved from fifth to second in the rankings of Italian cities. This ranking is the result of careful territorial monitoring for 10 years and ensures the clarity and precision of the analysis and a more precise representation of reality. In particular, the smart city index also deals with new thematic areas that highlight different aspects of urban development, such as aspects related to $\mathrm{Wi}-\mathrm{Fi}$, alternative energy, smart networks, digital justice, urban security and digital security.

Finally, at the level of these practices the Masterplan has been defined in the city of Turin. This document has held the role of the operational reference point for the organization of smart city activities and projects, both as regards the city's own funds or ministerial funds, both European funds and private initiatives.

An indicative measure of these practices can regard the intensity of the calls and the correlated value delivered from smart city investments [83]. Also, in this direction, the extent of the indexes developed in the smart city context is a measure that can give information on the evolution of innovations and progress [84]. Furthermore, the intensity of planning frameworks are a fundamental measure to address toward a global sustainability [85].

\subsection{Performance Practices}

The empirical research has shown that the satisfaction of the actors in a market exchange is a function of the expectations related to some attributes and judgments related to the performance of the attributes themselves, therefore the performance analysis has been considered a technique useful for evaluating different marketing elements [86]. Based on these considerations, interesting business performance models have been defined, which integrate the following value components [87].

It is possible to distinguish [75]:

- "provision practices" that ensure that the value proposition is met;

- "operational practices" that integrate resources in order to support the creation of value;

- "problem findings practices" that identify problems with the creation of customer value and the customer's need for new forms of value creation;

- "problem solving practices" that help solve customer problems.

In the smart cities context, the modern city aims to become a dynamic and at- 
tractive city, capable of creating sustainable wealth for the actors that interact in the ecosystem. Through the engineering activities, the city will have to become the centre of activities designed to facilitate exchanges and provide high-performance services to businesses and citizens. Therefore, performance services will be increasingly important and the level of performance of smart city value propositions must be monitored. For this reason, the city authorities intend to establish a reference model for measuring the performance of cities in environmental, economic and social terms, in order to create an international smart city standard to serve city residents [88].

Regarding the city of Turin, the activities performance was constantly monitored. In 2014, an alignment review of the 45 ideas of the SMILE project was carried out with European calls, the assessment of the metropolitan potential of ideas and projects and the presentation of PON to finance mature SMILE ideas. Depending on the level of performance, the city won the SMART CITY 2014 award. The award was promoted by SMAU and ANCI for the implementation of the SMILE masterplan defined as "innovative project, a virtuous example of the development of modern smart cities".

In this regard, a possible measure of performance practice is identified through the analysis of the triple helix model, which gives a reference framework for the analysis of knowledge-based innovation systems, and relates the dynamic relationships between university, industry and government [57].

\subsection{Innovation Practices}

Nowadays, understanding and adapting to innovation is essential, also because technology is growing always faster. The actors have to accept the inevitability to change and it is important to define a management approach that finds a balance between traditional activities and innovations [89].

Innovation can be defined as the result of an interaction between technological opportunities and user needs, so the focus is on the interaction between producers and users of innovation [90]. In this sense, even the collaboration between educational institutions and industry can result in increasing the intensity of the innovations developed and the value of the co-creation achieved [28].

Another important aspect is recovered from participatory design and creative practices to co-create knowledge [29]. Indeed, cooperation practices and the use of internal and external sources of information influence the propensity to introduce innovations in the services market. Several analyses also show that actors with information from market and internal sources, as well as companies involved in scientific collaboration for their product innovations, are more likely to introduce innovations. Instead, information from competitors seems to have a negative influence on the degree of innovation [91].

Therefore, to become innovative actors need to learn new skills and routines to develop the full potential of open innovation practices [92].

From a territorial point of view, smart city represents an urban innovation. 
The connotation of an intelligent city represents the city's innovation connecting management, politics and technology. Therefore, an intelligent city can be considered a contextualised interaction between technological innovation, managerial and organizational innovation and political innovation [33].

As for the city of Turin, several innovative practices have been defined through a project called "Public Innovation Procurement" in the areas of high potential innovation of the city linked to the smart city strategy. Public procurement innovation practices refer to the process of the innovation and to the outcomes connected. The public procurement contract starts with the research and development of products, services or processes, which do not exist yet. Starting from a specific need, it is developed a suitable solution able to support innovative activities, offering the perfectly suited product, service or process. In addition, it is possible that the public procurer, instead of renewing or replicating existing contracts, chooses a product, service or process that is new to the market or simply new to the public procurer [93]. These practices recover a central role to contribute to satisfying unsatisfied human needs and solving societal problems [94]. These practices provide: capacity building actions for internal staff, including specialized training; support in conducting the analysis of the demand and comparison with the pre-tender market; preparation of standard procedures and models; participation in national and European working groups; experimentation of procedures, also through the participation in European projects. Possible prosecution benefits include: better management of urban areas, greater support for innovation and market competitiveness, greater qualification of public demand through strategic procurement planning and greater professionalization of supply stations.

Continuing, a measure of innovative practices could be considered the extent of project aimed at innovation and digitalization of different urban processes [33].

\section{Managerial Implications}

In this paper, the concept of smart city is investigated as open and user driven innovation environment, which can be considered as a government model suitable for dealing with environmental dynamism and instability. A main role connected with the smart cities is played by new information and communication technologies, which help to reduce distances between the various social actors, engaging them as the key determinants of city welfare. Other important elements for the well-being of cities are infrastructures aimed at ensuring the spread of education and innovation, networks between businesses and governments, existence of citizens and enterprises capable of supporting innovation and quality of services. In the debate about smart cities, this work highlights how to effectively manage them, not only to focus on the use of new information and communication technologies, but also to increase and strengthen the level of interaction and collaboration among the various social actors involved in value 
generation processes [95]. Therefore, the uniqueness of the work lies on the attempt to highlight the value co-creation practices proposed by various scholars within service research [56] [66] [96] [97] [98] in the urban sector, considering them as a decisive stimulus for the activation of consolidated and lasting relations between social stakeholders.

In line with these considerations, this paper can provide important managerial implications, highlighting the role of co-creation practices as a key factor, which can influence the social position and the degree of influence of social actors within a given context [99]. In fact, the benefits of relationships between social actors have a personal relevance, but they also affect the broader network of relationships that each actor is able to build [100]. It is not a coincidence that benefits such as trust and co-operation, which are relevant to the individual in the immediate future, can also have wider implications for the whole context in which the latter is operating [101]. On that trail, [96] [102] [103] emphasize how co-creation practices are particularly significant for managing relationships between social actors, representing a possible approach towards creating a global value to be distributed to all those who took part in its generation. Actually, the efforts made in co-creation practices exerts an influence on the relationships between social actors and the organizational structure of the considered context [104]. In this regard, [27] illustrate how value co-creation practices are an effective tool for improving the results pursued in different areas of administrative life, underlining that an adequate combination of activities carried out by administrators, citizens-users, technology and other players in social life leads to improved performances. Also [105] emphasize the role of value-sharing practices, pointing out the importance of dialogue and the development of appropriate interactions between social actors in obtaining effective propositions of value. In this way it is possible to attract a large number of social actors, making necessary, through suitable co-creation practices, to be more effective in allocating resources.

The work, therefore, in the light of the considerations so far formulated, highlights the importance of value-added practices as tools to facilitate the involvement of a number of social actors, who are differently interested in contributing to the definition of processes of value generation [106].

From a theoretical point of view, the work connects the concept of smart city [1] [2] [3] with the service ecosystem theory [107] [108], exploiting this perspective as a model to better understood the process of value in the urban context.

\section{Conclusion, Limitations and Future Research}

The work, starting from the innovative and diversified concept of smart city, discusses the value co-creation practices as a possible value driven in an urban service ecosystem. This analysis identifies eight practices and the correlated measures in order to support and lead the transformation territorial process. However, it presents the limit to be based on a single case study related to the 
city of Turin and not to other cities. In fact, this eventuality would have allowed making appropriate comparisons, highlighting parallels and differences that could guarantee a more reliable and consistent generalization of the results. Therefore, future research could destine efforts to perform other researches based on multiple case studies in order to expand the observation object. In addition, in the view of smart city as a service ecosystem, it could be interesting to investigate its levels (micro, meso and macro), focusing on functionalities and actors that constitute each level.

\section{Conflicts of Interest}

The authors declare no conflicts of interest regarding the publication of this paper.

\section{References}

[1] Komninos, N. (2002) Intelligent Cities: Innovation, Knowledge Systems, and Digital Spaces. Taylor \& Francis, Oxfordshire.

[2] Aurigi, A. (2005) Making the Digital City: The Early Shaping of Urban Internet Space. Ashgate Publishing, Ltd., Farnham.

[3] Hollands, R.G. (2008) Will the Real Smart City Please Stand up? Intelligent, Progressive or Entrepreneurial? City, 12, 303-320. https://doi.org/10.1080/13604810802479126

[4] Troisi, O., Carrubbo, L., Maione, G. and Torre, C. (2016) The More, the Merrier: Co-Working as Practical Expression of Value Co-Creation in Sharing Economy. In: Russo-Spena, T. and Mele, C., Eds., 26th Annual RESER Conference 2016, New Perspectives for Business and Society, 8-10 September, 1130-1144.

[5] Troisi, O., Carrubbo, L., Maione, G. and Torre, C. (2017) Unity Is Strength: CoCreating Value in Working Context. Journal of Business and Economics, 8, 97-104.

[6] Vargo, S.L. and Lusch, R.F. (2016) Institutions and Axioms: An Extension and Update of Service-Dominant Logic. Journal of the Academy of Marketing Science, 44, 5-23. https://doi.org/10.1007/s11747-015-0456-3

[7] Vargo, S.L., Maglio, P.P. and Akaka, M.A. (2008) On Value and Value Co-Creation: A Service Systems and Service Logic Perspective. European Management Journal, 26, 145-152. https://doi.org/10.1016/j.emj.2008.04.003

[8] Frow, P., McColl-Kennedy, J.R. and Payne, A. (2016) Co-Creation Practices: Their Role in Shaping a Health Care Ecosystem. Industrial Marketing Management, 56, 24-39. https://doi.org/10.1016/j.indmarman.2016.03.007

[9] Molles, M.C., Cahill, J.F. and Laursen, A. (1999) Ecology: Concepts and Applications (No. QH541. M55 2013). WCB/McGraw-Hill, Boston.

[10] Chapin, F.S., Matson, P.A. and Mooney, H.A. (2002) Terrestrial Decomposition. Springer, New York, 151-175.

[11] Vargo, S.L. (2009) Toward a Transcending Conceptualization of Relationship: A Service-Dominant Logic Perspective. Journal of Business \& Industrial Marketing, 24, 373-379. https://doi.org/10.1108/08858620910966255

[12] Mars, M.M., Bronstein, J.L. and Lusch, R.F. (2012) The Value of a Metaphor: Organizations and Ecosystems. Organizational Dynamics, 41, 271-280. https://doi.org/10.1016/j.orgdyn.2012.08.002 
[13] Akaka, M.A., Vargo, S.L. and Lusch, R.F. (2013) The Complexity of Context: A Service Ecosystems Approach for International Marketing. Journal of Marketing Research, 21, 1-20.

[14] Chandler, J.D. and Lusch, R.F. (2015) Service Systems: A Broadened Framework and Research Agenda on Value Propositions, Engagement, and Service Experience. Journal of Service Research, 18, 6-22. https://doi.org/10.1177/1094670514537709

[15] Gherardi, S. and Nicolini, D. (2002) Learning in a Constellation of Interconnected Practices: Canon or Dissonance? Journal of Management Studies, 39, 419-436. https://doi.org/10.1111/1467-6486.t01-1-00298

[16] Reckwitz, A. (2002) Toward a Theory of Social Practices: A Development in Culturalist Theorizing. European Journal of Social Theory, 5, 243-263. https://doi.org/10.1177/13684310222225432

[17] Frow, P., McColl-Kennedy, J.R., Hilton, T., Davidson, A., Payne, A. and Brozovic, D. (2014) Value Propositions: A Service Ecosystem Perspective. Marketing Theory, 14, 327-351. https://doi.org/10.1177/1470593114534346

[18] Prahalad, C.K. and Ramaswamy, V. (2004) Co-Creation Experiences: The Next Practice in Value Creation. Journal of Interactive Marketing, 18, 5-14. https://doi.org/10.1002/dir.20015

[19] Herstatt, C. and Von Hippel, E. (1992) From Experience: Developing New Product Concepts via the Lead User Method: A Case Study in a "Low-Tech" Field. Journal of Product Innovation Management, 9, 213-221.

[20] Lagrosen, S. (2005) Customer Involvement in New Product Development: A Relationship Marketing Perspective. European Journal of Innovation Management, 8, 424-436. https://doi.org/10.1108/14601060510627803

[21] Von Hippel, E., Thomke, S. and Sonnack, M. (1999) Creating Breakthroughs at 3M. Harvard Business Review. European Journal of Innovation Management, 8, 424-436.

[22] Walter, A. (2003) Relationship-Specific Factors Influencing Supplier Involvement in Customer New Product Development. Journal of Business Research, 56, 721-733. https://doi.org/10.1016/S0148-2963(01)00257-0

[23] Echeverri, P. and Skålén, P. (2011) Co-Creation and Co-Destruction: A Practice-Theory Based Study of Interactive Value Formation. Marketing Theory, 11, 351-373. https://doi.org/10.1177/1470593111408181

[24] Marcos-Cuevas, J., et al. (2015) Marriage of Inconvenience: Value Co-Destruction in an Inter-Dependent Supply Chain Relationship. In: Robinson Jr., L., Ed., Marketing Dynamism \& Sustainability: Things Change, Things Stay the Same..., Springer, Cham, 378-381. https://doi.org/10.1007/978-3-319-10912-1_131

[25] Kjellberg, H. and Helgesson, C.F. (2007) On the Nature of Markets and Their Practices. Marketing Theory, 7, 137-162. https://doi.org/10.1177/1470593107076862

[26] Skålén, P., Gummerus, J., von Koskull, C. and Magnusson, P. (2014) Exploring Value Propositions and Service Innovation: A Service-Dominant Logic Study. Journal of the Academy of Marketing Science, 43, 137-158. https://doi.org/10.1007/s11747-013-0365-2

[27] DeVries, S., Beijaard, D. and Buitink, J. (2007) Learning in the Context of Co-Creation of Educational Practices. In: Ax, J. and Ponte, P., Eds., Critiquing praxis. Conceptual and Empirical Trends in the Teaching Profession, Sense Publishers, Rotterdam.

[28] Golooba, M. and Ahlan, A.R. (2013) Service Value Co-Creation in Research \& In- 
novation Practices in Higher Education Institutions in Malaysia. Procedia Technology, 11, 342-347. https://doi.org/10.1016/j.protcy.2013.12.200

[29] Langley, J. (2015) Thinking with Your Hands: Participatory Design and Creative Practices as Knowledge Co-Creation. Sheffield Hallam University Research Archive (SHURA).

[30] Dameri, R.P. (2013) Searching for Smart City Definition: A Comprehensive Proposal. International Journal of Computers \& Technology, 11, 2544-2551. https://doi.org/10.24297/ijct.v11i5.1142

[31] Cocchia, A. (2014) Smart and Digital City: A Systematic Literature Review. In: Dameri, R. and Rosenthal-Sabroux, C., Eds., Smart City, Springer, Cham, 13-43. https://doi.org/10.1007/978-3-319-06160-3_2

[32] Peris-Ortiz, M., Bennett, D.R. and Yábar, D.P.B. (2017) Sustainable Smart Cities. In: Innovation, Technology, and Knowledge Management, Springer International Publishing Switzerland, Cham. https://doi.org/10.1007/978-3-319-40895-8

[33] Nam, T. and Pardo, T.A. (2011) Conceptualizing Smart City with Dimensions of Technology, People, and Institutions. Proceedings of the 12 th Annual International Digital Government Research Conference: Digital Government Innovation in Challenging Times, College Park, 12-15 June 2011, 282-291. https://doi.org/10.1145/2037556.2037602

[34] Eriksson-Zetterquist, U., Müllern, T. and Styhre, A. (2011) Organization Theory: A Practice Based Approach. Oxford University Press, Oxford, UK.

[35] Garvin, D.A. (1993) Building a Learning Organization. Harvard Business Review, 71, 78-91.

[36] Loia, V., Maione, G., Tommasetti, A., Torre, C., Troisi, O. and Botti, A. (2016) Toward Smart Value Co-Education. In: Uskov, V., Howlett, R. and Jain, L., Eds., Smart Education and e-Learning 2016, Springer International Publishing, Berlin, 61-71. https://doi.org/10.1007/978-3-319-39690-3_6

[37] Anttiroiko, A.V. (2012) Urban Planning 2.0. International Journal of E-Planning Research (IJEPR), 1, 16-30. https://doi.org/10.4018/ijepr.2012010103

[38] Wachhaus, T.A. (2011) Governance as a Framework to Support Informatics. Innovation Journal, 16, 1-14.

[39] Tommasetti, A., Vesci, M. and Troisi, O. (2015) The Internet of Things and Value Co-Creation in a Service-Dominant Logic Perspective. In: Colace, F., De Santo, M., Moscato, V., Picariello, A., Schreiber, F.A. and Tanca, L., Eds., Data Management in Pervasive Systems, Springer, Cham, 3-18. https://doi.org/10.1007/978-3-319-20062-0_1

[40] Schaffers, H., Komninos, N., Pallot, M., Trousse, B., Nilsson, M. and Oliveira, A. (2011) Smart Cities and the Future Internet: Towards Cooperation Frameworks for Open Innovation. In: Domingue, J., et al., Eds., The Future Internet. FIA 2011. Lecture Notes in Computer Science, Vol. 6656, Springer, Berlin, Heidelberg, 431-446. https://doi.org/10.1007/978-3-642-20898-0_31

[41] Yin, R.K. (2013) Validity and Generalization in Future Case Study Evaluations. Evaluation, 19, 321-332. https://doi.org/10.1177/1356389013497081

[42] Punch, M. (1994) Politics and Ethics in Qualitative Research. In: Denzin, N.K. and Lincoln, Y.S., Eds., Handbook of Qualitative Research, Sage Publications, Thousand Oaks, CA, 83-95.

[43] Sekaran, U. and Bougie, R. (2013) Research Methods for Business: A Skill Building Approach. John Willey and Sons, Hoboken, NJ. 
[44] Denzin, N.K. and Lincoln, Y.S. (1994) Handbook of Qualitative Research. Sage Publications, Inc., Thousand Oaks.

[45] AgendaDigitale (2017) Torino Smart City: Ecco la nostra idea di città innovativa. https://www.agendadigitale.eu/infrastrutture/torino-smart-city-ecco-la-nostra-ideadi-citta-innovativa/

[46] Toppeta, D. (2010) The Smart City Vision: How Innovation and ICT Can Build Smart, "Livable", Sustainable Cities. The Innovation Knowledge Foundation, Vol. 5, $1-9$

[47] Chourabi, H., Nam, T., Walker, S., Gil-Garcia, J.R., Mellouli, S., Nahon, K. and Scholl, H.J. (2012) Understanding Smart Cities: An Integrative Framework. IEEE 201245 th Hawaii International Conference on System Science (HICSS), Maui, HI, 4-7 January 2012, 2289-2297. https://doi.org/10.1109/HICSS.2012.615

[48] Whiteley, P.F. (2000) Economic Growth and Social Capital. Political Studies, 48, 443-466. https://doi.org/10.1111/1467-9248.00269

[49] Leana, C.R. and Van Buren, H.J. (1999) Organizational Social Capital and Employment Practices. Academy of Management Review, 24, 538-555.

https://doi.org/10.5465/amr.1999.2202136

[50] Blanchet, K. and James, P. (2011) How to Do (or Not to Do) - A Social Network Analysis in Health Systems Research. Health Policy and Planning, 27, 438-446. https://doi.org/10.1093/heapol/czr055

[51] Caragliu, A., Del Bo, C. and Nijkamp, P. (2011) Smart Cities in Europe. Journal of Urban Technology, 18, 65-82. https://doi.org/10.1080/10630732.2011.601117

[52] Widén-Wulff, G. and Ginman, M. (2004) Explaining Knowledge Sharing in Organizations through the Dimensions of Social Capital. Journal of Information Science, 30, 448-458. https://doi.org/10.1177/0165551504046997

[53] Tsai, W. and Ghoshal, S. (1998) Social Capital and Value Creation: The Role of Intrafirm Networks. Academy of Management Journal, 41, 464-476.

[54] Maak, T. (2007) Responsible Leadership, Stakeholder Engagement, and the Emergence of Social Capital. Journal of Business Ethics, 74, 329-343. https://doi.org/10.1007/s10551-007-9510-5

[55] Fukuyama, F. (2001) Social Capital, Civil Society and Development. Third World Quarterly, 22, 7-20. https://doi.org/10.1080/713701144

[56] Gilly, J.P. and Torre, A. (2000) Proximity Relations. Elements for an Analytical Framework. In: Green, M.B. and Mac Naughton, R.B., Eds., Industrial Networks and Proximity, Aldershot, Ashgate, 1-16.

[57] Lombardi, P., Giordano, S., Farouh, H. and Yousef, W. (2012) Modelling the Smart City Performance. Innovation: The European Journal of Social Science Research, 25, 137-149. https://doi.org/10.1080/13511610.2012.660325

[58] Helliwell, J.F. and Putnam, R.D. (1999) Education and Social Capital. NBER Working Paper Series, National Bureau of Economic Research, Cambridge, MA. https://doi.org/10.3386/w7121

[59] Healy, T. and Côté, S. (2001) The Well-Being of Nations: The Role of Human and Social Capital. Education and Skills. Organisation for Economic Cooperation and Development, Paris, France.

[60] McMahon, W.W. (2004) The Social and External Benefits of Education. In: Johnes, G. and Johnes, J., Eds., International Handbook on the Economics of Education, Edward Elgar Publishing, Cheltenham, 211-259.

https://doi.org/10.4337/9781845421694.00011 
[61] Chiu, C., Hsu, M. and Wang, E.T.G. (2006) Understanding Knowledge Sharing in Virtual Communities: An Integration of Social Capital and Social Cognitive Theories. Decision Support Systems, 42, 1872-1888. https://doi.org/10.1016/j.dss.2006.04.001

[62] Ballinger, L.B. and Ballinger, R.A. (1972) Sign, Symbol and Form. Van Nostrand Reinhold Company, New York.

[63] Jalongo, M.R., Isenberg, J.P. and Gerbracht, G. (1995) Teachers' Stories: From Personal Narrative to Professional Insight. The Jossey-Bass Education Series. Jossey-Bass, Inc., San Francisco, CA.

[64] smau (2014) Torino SMILE: Smart Mobility, Inclusion, Life \& Health, Energy. Il caso Città di Torino.

https://www.smau.it/torino14/success_stories/torino-smile-smart-mobility-inclusio n-life-health-energy-il-caso-smart-city-citta-di-torino/

[65] Mathieu, J.E., et al. (2000) The Influence of Shared Mental Models on Team Process and Performance. Journal of Applied Psychology, 85, 273-283. https://doi.org/10.1037/0021-9010.85.2.273

[66] Akaka, M.A., Corsaro, D., Kelleher, C., Maglio, P.P., Seo, Y., Lusch, R.F. and Vargo, S.L. (2014) The Role of Symbols in Value Cocreation. Marketing Theory, 14, 311-326. https://doi.org/10.1177/1470593114534344

[67] Storbacka, K. and Nenonen, S. (2011) Scripting Markets: From Value Propositions to Market Propositions. Industrial Marketing Management, 40, 255-266. https://doi.org/10.1016/j.indmarman.2010.06.038

[68] Alexander, M. and Jaakkola, E. (2011) Exploring Value Co-Creation within Networks: Actor-to-Actor Service Provision within a Public Transport Service System. Industrial Marketing and Purchasing Conference, September 2011.

[69] Kitchin, R. (2014) The Real-Time City? Big Data and Smart Urbanism. GeoJournal, 79, 1-14. https://doi.org/10.1007/s10708-013-9516-8

[70] Snyder, F. (1994) Soft Law and Institutional Practice in the European Community. In: Martin, S., Ed., The Construction of Europe, Springer, Dordrecht, 197-225. https://doi.org/10.1007/978-94-015-8368-8_10

[71] Gargiulo, C., Pinto, V. and Zucaro, F. (2013) EU Smart City Governance. TeMA-Journal of Land Use, Mobility and Environment, 6, 356-370.

[72] Barile, S. and Polese, F. (2010) Linking the Viable System and Many-to-Many Network Approaches to Service-Dominant Logic and Service Science. International Journal of Quality and Service Sciences, 2, 23-42. https://doi.org/10.1108/17566691011026586

[73] Lawrence, T.B., Hardy, C. and Phillips, N. (2002) Institutional Effects of Interorganizational Collaboration: The Emergence of Proto-Institutions. The Academy of Management Journal, 45, 281-290.

[74] Gummesson, E. and Mele, C. (2010) Marketing as Value Co-Creation through Network Interaction and Resource Integration. Journal of Business Market Management, 4, 181-198. https://doi.org/10.1007/s12087-010-0044-2

[75] Skålén, P., Gummerus, J., von Koskull, C. and Magnusson, P.R. (2015) Exploring Value Propositions and Service Innovation: A Service-Dominant Logic Study. Journal of the Academy of Marketing Science, 43, 137-158. https://doi.org/10.1007/s11747-013-0365-2

[76] Chalmers Thomas, T., Price, L.L. and Schau, H.J. (2012) When Differences Unite: Resource Dependence in Heterogeneous Consumption Communities. Journal of 
Consumer Research, 39, 1010-1033. https://doi.org/10.1086/666616

[77] Jaworski, B. and Kohli, A.K. (2006) Co-Creating the Voice of the Customer. In: Lusch, R.F. and Vargo, S.L., Eds., The Service-Dominant Logic of Marketing. Dialog, Debate and Directions, M.E. Sharpe, Armonk, NY, 109-117.

[78] Etgar, M. (2006) Co-Production of Services: A managerial Extension. In: Lusch, R.F. and Vargo, S.L., Eds., The Service Dominant Logic of Marketing. Dialog, Debate and Directions, M.E. Sharpe, Armonk, NY, 128-138.

[79] Plé, L. and Chumpitaz Cáceres, R. (2010) Not Always Co-Creation: Introducing Interactional Co-Destruction of Value in Service-Dominant Logic. Journal of Services Marketing, 24, 430-437. https://doi.org/10.1108/08876041011072546

[80] Zanella, A., Bui, N., Castellani, A., Vangelista, L. and Zorzi, M. (2014) Internet of Things for Smart Cities. IEEE Internet of Things Journal, 1, 22-32. https://doi.org/10.1109/JIOT.2014.2306328

[81] Kjellberg, H. and Helgesson, C.F. (2006) Multiple Versions of Markets: Multiplicity and Performativity in Market Practice. Industrial Marketing Management, 35, 839-855. https://doi.org/10.1016/j.indmarman.2006.05.011

[82] Filipponi, L., Vitaletti, A., Landi, G., Memeo, V., Laura, G. and Pucci, P. (2010) Smart City: An Event Driven Architecture for Monitoring Public Spaces with Heterogeneous Sensors. IEEE 2010 4th International Conference on Sensor Technologies and Applications, Venice, 18-25 July 2010, 281-286. https://doi.org/10.1109/SENSORCOMM.2010.50

[83] Washburn, D., Sindhu, U., Balaouras, S., Dines, R.A., Hayes, N. and Nelson, L.E. (2009) Helping CIOs Understand "Smart City" Initiatives. Growth, 17, 1-17.

[84] Neirotti, P., De Marco, A., Cagliano, A.C., Mangano, G. and Scorrano, F. (2014) Current Trends in Smart City Initiatives: Some Stylised Facts. Cities, 38, 25-36. https://doi.org/10.1016/j.cities.2013.12.010

[85] Zygiaris, S. (2013) Smart City Reference Model: Assisting Planners to Conceptualize the Building of Smart City Innovation Ecosystems. Journal of the Knowledge Economy, 4, 217-231. https://doi.org/10.1007/s13132-012-0089-4

[86] Martilla, J.A. and James, J.C. (1977) Importance-Performance Analysis. Journal of Marketing, 41, 77-79. https://doi.org/10.1177/002224297704100112

[87] Payne, A., Holt, S. and Frow, P. (2001) Relationship Value Management: Exploring the Integration of Employee, Customer and Shareholder Value and Enterprise Performance Models. Journal of Marketing Management, 17, 785-817. https://doi.org/10.1362/026725701323366827

[88] Hall, P. (1988) Cities of Tomorrow. Blackwell Publishers, Hoboken, NJ.

[89] Utterback, J. (1994) Mastering the Dynamics of Innovation: How Companies Can Seize Opportunities in the Face of Technological Change. Harvard Business School Press, Brighton, Boston, MA.

[90] Lundvall, B.Å. (2009) Innovation as an Interactive Process: User-Producer Interaction to the National System of Innovation. African Journal of Science, Technology, Innovation and Development, 1, 10-34.

[91] Mention, A.L. (2011) Co-Operation and Co-Opetition as Open Innovation Practices in the Service Sector: Which Influence on Innovation Novelty? Technovation, 31, 44-53. https://doi.org/10.1016/j.technovation.2010.08.002

[92] Vanhaverbeke, W., Van de Vrande, V. and Chesbrough, H. (2008) Understanding the Advantages of Open Innovation Practices in Corporate Venturing in Terms of Real Options. Creativity and Innovation Management, 17, 251-258. 
https://doi.org/10.1111/j.1467-8691.2008.00499.x

[93] European Commission (2014) Commission Notice "Guidance on Innovation Procurement".

https://ec.europa.eu/digital-single-market/en/news/commission-notice-guidance-in novation-procurement-published

[94] Edquist, C. and Zabala-Iturriagagoitia, J.M. (2012) Public Procurement for Innovation as Mission-Oriented Innovation Policy. Research Policy, 41, 1757-1769. https://doi.org/10.1016/j.respol.2012.04.022

[95] Anttiroiko, A.V., Valkama, P. and Bailey, S.J. (2014) Smart Cities in the New Service Economy: Building Platforms for Smart Services. AI \& Society, 29, 323-334. https://doi.org/10.1007/s00146-013-0464-0

[96] Gittell, R. and Vidal, A. (1998) Community Organizing: Building Social Capital as a Development Strategy. Newbury Park, Sage Publications, Thousand Oaks, CA.

[97] Duysters, G. and Lemmens, C. (2003) Alliance Group Formation Enabling and Constraining Effects of Embeddedness and Social Capital in Strategic Technology Alliance Networks. International Studies of Management \& Organization, 33, 49-68. https://doi.org/10.1080/00208825.2003.11043683

[98] Storbacka, K. and Nenonen, S. (2011) Markets as Configurations. European Journal of Marketing, 45, 241-258. https://doi.org/10.1108/03090561111095685

[99] Blanchet, K. and James, P. (2012) The Role of Social Networks in the Governance of Health Systems: The Case of Eye Care Systems in Ghana. Health Policy and Planning, 28, 143-156. https://doi.org/10.1093/heapol/czs031

[100] Tommasetti, A., Botti, A., Troisi, O. and Vesci, M. (2014) Customer satisfaction, commitment, loyalty ed implicazioni nella governance delle università: Una ricerca esplorativa. Azienda Pubblica, 3, 219-242.

[101] Fukuyama, F. (1995) Trust: The Social Virtues and the Creation of Prosperity. Free Press Paperbacks, New York, NY.

[102] Putnam, R.D. (2000) Bowling Alone: The Collapse and Revival of American Community. Simon \& Schuster, New York, NY.

[103] Szreter, S. and Woolcock, M. (2004) Health by Association? Social Capital, Social Theory, and the Political Economy of Public Health. International Journal of Epidemiology, 33, 650-667. https://doi.org/10.1093/ije/dyh013

[104] Schau, H.J., Muñiz Jr., A.M. and Arnould, E.J. (2009) How Brand Community Practices Create Value. Journal of Marketing, 73, 30-51. https://doi.org/10.1509/jmkg.73.5.30

[105] Ballantyne, D., Frow, P., Varey, R.J. and Payne, A. (2011) Value Propositions as Communication Practice: Taking a Wider View. Industrial Marketing Management, 40, 202-210. https://doi.org/10.1016/j.indmarman.2010.06.032

[106] Ciasullo, M.V. and Troisi, O. (2015) The Creation of Sustainable Value in SMEs. A Case Study. 14th Toulon-Verona (ICQSS) Conference Excellence in Services-Conference Proceedings, Università di Alicante, September 2011.

[107] Vargo, S.L. and Lusch, R.F. (2010) From Repeat Patronage to Value Co-Creation in Service Ecosystems: A Transcending Conceptualization of Relationship. Journal of Business Market Management, 4, 169-179. https://doi.org/10.1007/s12087-010-0046-0

[108] Vargo, S.L. and Akaka, M.A. (2012) Value Cocreation and Service Systems (Re) Formation: A Service Ecosystems View. Service Science, 4, 207-217.

https://doi.org/10.1287/serv.1120.0019 